\title{
OPTIMAL FACTOR TAXATION UNDER WAGE BARGAINING - A DYNAMIC PERSPECTIVE
}

\author{
ERKKI KOSKELA \\ LEOPOLD VON THADDEN
}

CESIFO WORKING PAPER NO. 836

CATEGORY 1: PUBlic FinANCE

JANUARY 2003

An electronic version of the paper may be downloaded

- from the SSRN website: www.SSRN.com

- from the CESifo website: www.CESifo.de 


\title{
OPTIMAL FACTOR TAXATION UNDER WAGE BARGAINING - A DYNAMIC PERSPECTIVE
}

\begin{abstract}
We consider the issue of steady-state optimal factor taxation in a Ramsey-type dynamic general equilibrium setting with two distinct distortions: i) taxes on capital and labour are the only available tax instruments for raising revenues, and ii) labour markets are subject to a static inefficiency resulting from wage bargaining. If considered in isolation, under broad assumptions the two distortions create conflicting demands on the wage tax, while calling for a zero capital tax. By combining the two distortions, we arrive at the conclusion that both instruments should be used, implying that the zero-capital tax result in general is no longer valid under imperfectly competitive labour markets.
\end{abstract}

JEL Classification: E62, H21, J51.

Keywords: optimal taxation, imperfectly competitive labour markets, capital accumulation..

\author{
Erkki Koskela \\ Department of Economics \\ P.O.Box 54 (Unioninkatu37) \\ FIN-00014 University of Helsinki \\ Finland \\ erkki.koskela@helsinki.fi
}

Leopold von Thadden

Research Centre, Deutsche Bundesbank

Wilhelm-Epstein-Strasse 14

60431 Frankfurt/Main

Germany

leopold.von-thadden@bundesbank.de

Comments by Heinz Herrmann, Johannes Hoffman and seminar participants in Mannheim and Uppsala are gratefully acknowledged. Koskela wishes to thank the Research Centre of the Deutsche Bundesbank for its financial support and its hospitality. Von Thadden wishes to thank the Research Unit on Economic Structures and Growth (RUESG) at the University of Helsinki for its hospitality. The views expressed in this paper are those of the authors and do not necessarily reflect the views of the Deutsche Bundesbank. 


\section{Introduction}

This paper studies the Ramsey problem of optimal factor taxation under commitment in an infinite horizon framework which deviates from a first-best representative agent economy in two important aspects. First, to raise revenues the government must use distortionary, second-best taxation. More specifically, following research along the lines of Chamley (1986) and Judd (1985), we assume that proportional taxes on wages and capital income are the only tax instruments for financing some exogenously specified sequence of government expenditures. Second, the economy is taken to be imperfectly competitive in the sense that the labour market is subject to a static wage bargain. Owing to this feature, wages are set with a mark-up compared with a fully competitive outcome, leading to a socially sub-optimal employment level. We assume that the institutional set-up which generates this labour market inefficiency is taken as given by the fiscal agent when designing the mix of factor taxes, implying that corrective taxes or subsidies are the only channel to address the labour market distortion.

As shown in seminal studies by Chamley (1986) and Judd (1985), the first distortion resulting from restrictions on the set of available taxes, if taken in isolation, requires under broad assumptions that the long-run second-best tax rate of capital income should be zero, while the labour tax rate should be positive. Essentially, this result can be seen as an implication of the uniform taxation principle which states that consumption at different dates should not be subject to differential taxation, as would be the case with a positive capital tax rate. ${ }^{1}$ The purpose of this paper is to show that this reasoning may well require some modification if labour markets are assumed to be imperfectly competitive. To this end, we present a simple collective wage bargaining structure in which the representative firm is 'small' and its invest-

\footnotetext{
${ }^{1}$ Alternatively, with capital acting as an input in an intertemporal framework, the result may also be inferred from the production efficiency principle, following Diamond and Mirrlees (1971).
} 
ment decision is made in a non-strategic manner, while the aggregate capital stock nevertheless acts period by period as a crucial input for the wage-setting process. As a result of this feature, the return rates to capital as perceived by the private sector and by the Ramsey planner are likely to be different. This, in turn, as we discuss from two perspectives, tends to invalidate the result of a steady-state zero-capital tax, making it instead advisable to use both tax instruments.

First, we consider a constellation in which, in a first-best sense, wage subsidies should be used to counteract the effects of wage mark-ups. Accordingly, from a second-best perspective the two distortions impose conflicting demands on the wage tax, i.e. a positive wage tax in line with the objective of generating revenues under distortionary taxation and a wage subsidy in order to correct for the labour market inefficiency. Addressing this 'conflict', our results indicate an interesting hierarchy of the use of the two tax instruments. Quite in line with the Chamley-Judd result, the labour tax is shown to bear the brunt of the revenue motive while a non-zero capital tax rate should be used, whenever possible, as a second-best tool to address the distortion in the labour market. More specifically, we establish that whenever the wage mark-up depends on the size of the capital stock a non-zero capital tax rate should assist the corrective taxation motive by mitigating the mark-up pricing of wage setters. In our set-up, this will be the case for standard aggregate production functions of the CES type under conventional assumptions regarding the timing of actions and the stock/flow distinction between physical capital and labour. As is discussed in more detail below, these findings are broadly in line with Judd $(1997,2002)$ and Guo and Lansing (1999) who stress the importance of potential discrepancies between private and social returns to capital and establish a role for second-best corrective capital taxation under imperfectly competitive product markets. However, there is an interesting twist to this since the focus of these papers is not on labour market imperfections. Moreover, Judd (2002) offers the conjecture that "while labour 
markets may also be imperfectly competitive due to unionization, union mark-ups are similar to labour-income taxation and do not create exploding distortions between social and private costs." (p. 419). Our analysis offers a counter-example to this conjecture in the sense that in our set-up discrepancies between private and social costs of capital are triggered by a distortion which is directly linked to the introduction of union mark-ups in an otherwise standard setting.

Second, by slightly modifying some details of the labour market specification, we derive a constellation in which the employment level resulting from the bargain does not depend on the wage tax, i.e. labour earns a rent. Upon this change, assuming that these rents cannot be fully taxed, the capital tax should now take on the role of counteracting the creation of rents. Qualitatively, this finding is in line with Correia (1996) and Jones, Manuelli, and Rossi (1997) who also allow for the possibility of rents in dynamic Ramsey settings, although not in the context of imperfectly competitive labour markets.

Our analysis proceeds in two stages. First, as a simple and transparent benchmark, we consider an economy with monopolistic wage setting along the lines of Gali (1995, 1996) and zero rents, reflecting price taking behaviour by firms and constant returns to scale in the two inputs labour and physical capital. The labour supply of the representative household is assumed to be elastic, and wages are set with a mark-up over the marginal rate of substitution between consumption and leisure, leading to underemployment compared with a fully competitive economy. Using this wage-setting condition in the implementability constraint of the Ramsey problem, we conclude that a non-zero capital tax should be used whenever the wage elasticity of labour demand and, thus, the mark-up is not constant, but rather varies with the capital intensity of production. Moreover, stressing the corrective taxation aspect of this finding, the optimal labour tax schedule is shown to have a component which has the opposite sign of the capital tax. Second, extending this benchmark 
economy, we allow for a right-to-manage bargaining framework along the lines of Layard, Nickell, and Jackman (1991) in which both firms and workers have some bargaining power and in which the outcome of the bargain depends on the level of unemployment benefits and the aggregate unemployment rate. Using the firstorder condition of this bargaining structure in the implementability constraint, we show that the optimal tax schedule depends in particular on how unemployment benefits are specified. As long as benefits are not proportional to the net wage, the qualitative findings of our benchmark economy carry over to the bargaining framework. Intuitively, this is the case because under this specification the labour market allocation resulting from the bargain depends on both the labour tax and the wage elasticity of labour demand, as in the benchmark economy. Hence, there is scope for a capital tax (or subsidy) to assist the corrective taxation motive. By contrast, if benefits are proportional to the net wage, the labour market allocation no longer responds to changes in the wage tax, which is consistent with findings established in Pissarides (1998). Consequently, there emerges a rent in the labour market, and our results generalize findings by Jones, Manuelli, and Rossi (1997) by allowing for wage bargaining. More specifically, if it is assumed that the rent cannot be fully taxed away (because there exists an exogenous, upper bound on the labour tax), the capital tax rate should be used as a tool for preventing the creation of rents. Then, whenever the rent correlates positively with the long-run capital stock, the capital tax should be positive to counteract the rent-creation process.

In the remainder of the paper we proceed as follows. Section 2 establishes the notation and presents our main findings within a simple benchmark economy with monopolistic wage setting. Section 3 allows for a richer right-to-manage wage bargain and highlights the importance of the specification of unemployment benefits for the optimal design of steady-state factor taxes. Section 4 discusses our main findings in the context of related literature. Section 5 offers some conclusions. 


\section{Optimal factor taxes under monopolistic wage setting}

We consider a dynamic general equilibrium framework in which infinitely lived households have preferences over consumption and leisure. There is one good which can be equally consumed or invested, and the aggregate production technology is characterized by constant returns to the two inputs labour and capital. The economy is in many ways standard, with the exception that labour markets are not fully competitive insofar as households have some market power when setting their wages, similar to Gali $(1995,1996){ }^{2}$

\subsection{Description of the economy}

There is a continuum of households and firms, each being of measure 1. The representative household has in every period $t$ a constant time endowment $L^{e}=1$ which the household divides between leisure $L_{t}$ and working hours $N_{t}$. Let the per household levels of output and physical capital be denoted by $Y_{t}$ and $K_{t}$. Production of output occurs according to the constant returns to scale technology $Y_{t}=F\left(K_{t}, N_{t}\right)$, with $F$ being increasing, continuously differentiable, and strictly concave. Capital depreciates at the constant rate $\delta \in(0,1)$. Since firms are 'small', they take the (correctly foreseen) sequence of factor prices as given and choose employment and capital according to the first-order conditions

$$
\begin{aligned}
w_{t} & =F_{N}\left(K_{t}, N_{t}\right) \\
r_{t} & =F_{K}\left(K_{t}, N_{t}\right),
\end{aligned}
$$

\footnotetext{
${ }^{2}$ Apart from this special feature, the set-up in this section follows closely the textbook version of optimal factor taxation under commitment by Sargent and Ljungqvist (2000, chapter 12).
} 
where $w_{t}$ and $r_{t}$ denote the gross wage rate and the gross return rate on capital, respectively. Hence, firms make zero profits, and the return on capital is distributed to households which own the economy's capital stock. In every period, the government finances a constant stream of government expenditures $G>0$, providing no utility to the representative household. The set of available tax instruments is restricted to proportional taxes on labour income $\left(\tau_{t}^{N}\right)$ and capital income $\left(\tau_{t}^{K}\right)$. Moreover, the government issues one-period bonds, yielding the flow budget constraint of the government

$$
G+B_{t}=\tau_{t}^{K} r_{t} K_{t}+\tau_{t}^{N} w_{t} N_{t}+\frac{B_{t+1}}{R_{t}},
$$

where $R_{t}$ denotes the gross return on a bond issued in period $t$ and redeemed in period $t+1$. Let $C_{t}$ denote the consumption level of the household in period $t$. Then, the resource constraint of the economy is given by

$$
G+C_{t}+K_{t+1}=F\left(K_{t}, N_{t}\right)+(1-\delta) K_{t}
$$

Preferences of households are time-separable, and the flow utility $u(C, L)$ is increasing, differentiable, strictly concave and, for further simplification, separable in leisure and consumption, i.e. $u_{C L}=0$. The objective of the household is to maximize

$$
\max \sum_{t=0}^{\infty} \beta^{t} u\left(C_{t}, 1-N_{t}\right),
$$

where $\beta \in(0,1)$ denotes the discount factor. To rationalize some wage-setting power on the part of households without introducing further heterogeneity into the set-up, let households be collectively organized in a trade union which acts as a monopolistic wage setter. Wages are set for one period, and, with the aggregate capital stock being predetermined by the investment and savings decisions of the previous period, the wage-setting behaviour takes into account the static constraint imposed by the labour demand schedule:

$$
N_{t}=N\left(w_{t}, K_{t}\right)
$$


The wage-setting specification rests on three key assumptions. i) Firms are too small to behave in a strategic manner vis-à-vis the outcome of the bargain, i.e. we abstract from the hold-up problem which typically arises under firm-specific bargaining. ii) The union disregards the effects of its wage-setting behaviour on capital income. iii) The behaviour of the union is myopic in the sense that intertemporal feedback-effects of wage decisions are not taken into account. ${ }^{3}$ We want to point out, however, that, despite these seemingly strong assumptions, the specification is naturally linked to a fully competitive set-up. In particular, with $\eta(N, K)=\frac{-N_{w} w}{N}$ denoting the wage elasticity of labour demand, the specification turns into the standard competitive case as $\eta$ tends to infinity.

Households consider tax-exempt government bonds and claims on physical capital as perfect substitutes, implying the no-arbitrage condition

$$
\left(1-\tau_{t+1}^{K}\right) r_{t+1}+1-\delta=R_{t}
$$

If one defines and normalizes the discount factors as

$$
q_{t}^{o}=\prod_{i=0}^{t-1} R_{i}^{-1}, \quad q_{0}^{o}=1,
$$

the present value budget constraint of the household can be written as

$$
\sum_{t=0}^{\infty} q_{t}^{o} C_{t}=\sum_{t=0}^{\infty} q_{t}^{o}\left(1-\tau_{t}^{N}\right) w_{t} N_{t}+\left[\left(1-\tau_{0}^{K}\right) r_{0}+1-\delta\right] K_{0}+B_{0}
$$

where $K_{0}$ and $B_{0}$ are initial holdings of capital and bonds and $\tau_{0}^{K}$ is the initial capital tax rate. Acting on behalf of its members, the trade union maximizes (5) over $C$ and $w$ subject to (6) and (7). Using $q_{t}^{o} / q_{t+1}^{o}=R_{t}$, this gives rise to the first-order conditions

$$
q_{t}^{o}=\beta^{t} \frac{u_{C}(t)}{u_{C}(0)}
$$

\footnotetext{
${ }^{3}$ When extending this set-up in Section 3, we rationalize this type of myopic wage-setting in a framework with sector-specific wage bargaining and turnover between sectors.
} 


$$
\begin{aligned}
u_{C}(t) & =\beta u_{C}(t+1)\left[\left(1-\tau_{t+1}^{K}\right) r_{t+1}+1-\delta\right] \\
\left(1-\tau_{t}^{N}\right) w_{t} & =\frac{u_{L}(t)}{u_{C}(t)} M_{t}
\end{aligned}
$$

where $M_{t}\left(N_{t}, K_{t}\right)=\frac{\eta\left(N_{t}, K_{t}\right)}{\eta\left(N_{t}, K_{t}\right)-1}$ in (10) denotes the mark-up of net wages over the marginal rate of substitution between leisure and consumption. ${ }^{4}$ For future reference, it is helpful to shed some light on the determinants of the wage mark-up. Let $k=K / N$ denote the capital intensity of production and, for illustration, consider a $C E S$ production function with constant returns to scale

$$
F(K, N)=\left[(1-\alpha) N^{\frac{\sigma-1}{\sigma}}+\alpha K^{\frac{\sigma-1}{\sigma}}\right]^{\frac{\sigma}{\sigma-1}}
$$

where $0<\alpha<1$ is the distribution parameter and $\sigma$ is the elasticity of substitution between capital and labour. Exploiting well-known properties of the $C E S$ production function, we provide the following summary for future reference:

Lemma Under the constant returns to scale CES production function the mark-up of the net wage over the marginal rate of substitution between leisure and consumption is a function of the capital intensity, with $M(K, N)=M(k)=\frac{\eta(k)}{\eta(k)-1}$ and

$$
\frac{\partial M}{\partial k}\left\{\begin{array}{l}
<0 \text { if } \sigma<1 \\
=0 \text { if } \sigma=1 \\
>0 \text { if } \sigma>1
\end{array}\right.
$$

Remark: For a derivation, see Appendix, part 1.

According to the lemma, the wage mark-up $M$ will be constant if the wage elasticity of labour demand $\eta$ is independent of the capital intensity. As is well known, this will be satisfied for the special case of a Cobb-Douglas function $(\sigma=1)$. However, under gross complementarity $(\sigma<1)$, a higher capital intensity, quite intuitively, increases

\footnotetext{
${ }^{4}$ Of course, for a well-defined optimization problem, the usual transversality conditions for the stocks of capital and government bonds need to be satisfied as well.
} 
the wage elasticity of labour demand (since the factor complementary to labour is now relatively more abundant) and, thus, reduces the wage mark-up. Conversely, under gross substitutability $(\sigma>1)$, the effect is of an opposite nature, i.e. a higher capital intensity reduces the wage elasticity of labour demand and, thus, increases the wage mark-up.

\subsection{Optimal taxation}

Given the revenue requirements implied by the sequence of government expenditures, the government is assumed to set its instruments in a manner which maximizes the utility of the representative household. Following Lucas and Stokey (1983), it has become common practice to solve this type of dynamic Ramsey problem by means of the primal approach which expresses the choice problem of the government in terms of quantities. Using the first-order conditions (8)-(10) to substitute out for prices and taxes in the intertemporal budget constraint of the representative household, one obtains the 'implementability' constraint:

$$
\sum_{t=0}^{\infty} \beta^{t}\left[u_{C}(t) C_{t}-u_{L}(t) N_{t} M_{t}\right]-A=0
$$

where $A$ is given by $A=u_{C}(0)\left\{\left[\left(1-\tau_{0}^{K}\right) F_{K}(0)+1-\delta\right] K_{0}+B_{0}\right\}$. When maximizing (5) subject to (4) and (12), let $\phi$ denote the value of the Lagrange multiplier associated with the implementability constraint. Moreover, let

$$
V\left(C_{t}, N_{t}, K_{t}, \phi\right)=u\left(C_{t}, 1-N_{t}\right)+\phi\left[u_{C}(t) C_{t}-u_{L}(t) N_{t} M_{t}\right]
$$

and rewrite the objective of the primal approach compactly as

$$
J=\sum_{t=0}^{\infty} \beta^{t}\left\{V\left(C_{t}, N_{t}, K_{t}, \phi\right)+\theta_{t}\left[F\left(K_{t}, N_{t}\right)+(1-\delta) K_{t}-G-C_{t}-K_{t+1}\right]\right\}-\phi A .
$$


With $K_{0}, B_{0}$ and some fixed initial capital tax rate $\tau_{0}^{K}$ being given, the first-order conditions of this 'pseudo-planning problem' can be calculated as follows ${ }^{5}$ :

$$
\begin{array}{rll}
K_{t+1} & : \quad \theta_{t}=\beta\left\{\theta_{t+1}\left[F_{K}(t+1)+1-\delta\right]+V_{K}(t+1)\right\} \\
C_{t} & : \quad V_{C}(t)=\theta_{t} \\
N_{t} & : \quad V_{N}(t)=-\theta_{t} F_{N}(t) \\
C_{0} & : \quad V_{C}(0)=\theta_{0}+\phi u_{C C}(0)\left\{\left[\left(1-\tau_{0}^{K}\right) F_{K}(0)+1-\delta\right] K_{0}+B_{0}\right\} \\
N_{0} & : \quad V_{N}(0)=-\theta_{0} F_{N}(0)
\end{array}
$$

where

$$
\begin{aligned}
V_{C}(t) & =u_{C}(t)+\phi\left(u_{C C}(t) C(t)+u_{C}(t)\right) \\
V_{N}(t) & =-u_{L}(t)+\phi\left(u_{L L}(t) N(t) M(t)-u_{L}(t) M(t)+u_{L}(t) K(t) M_{K}(t)\right) \\
V_{K}(t+1) & =-\phi u_{L}(t+1) N(t+1) M_{K}(t+1) .
\end{aligned}
$$

Note that equation (15) captures the standard intertemporal trade-off described by the Euler-equation from the household's optimization problem as long as $V_{K}(t+$ $1)=0$. By contrast, $V_{K}(t+1) \neq 0$ indicates that the returns to investments in physical capital as perceived by the private sector and the Ramsey planner no longer coincide. For the remainder of this analysis, we follow the literature in assuming that there exists a solution to the Ramsey problem which converges to a timeinvariant allocation, giving rise to a unique combination of steady-state factor taxes. Schedules for optimal taxes can be recovered by combining the first-order conditions of the pseudo-planning problem and the household. More specifically, by using the steady-state versions of (9) and (15) one obtains for the optimal capital income tax rate

$$
\tau^{K}=-\frac{V_{K}}{V_{C} F_{K}}=\frac{\phi u_{L} N}{V_{C} F_{K}} M_{K}
$$

\footnotetext{
${ }^{5}$ As discussed further below, since the time-zero capital stock can be taxed without deadweight loss some restriction with respect to $\tau_{0}^{K}$ typically needs to be imposed in order to ensure that the implementability constraint is binding.
} 
Analogously, combining the steady-state versions of (10), (16) and (17) yields for the optimal labour tax rate

$$
\begin{aligned}
\tau^{N} & =1-z(M) \\
\text { where } z(M) & =\frac{1+\phi\left(1+u_{C C} \frac{C}{u_{C}}\right)}{\frac{1}{M}+\phi\left(1-u_{L L} \frac{L}{u_{L}} \frac{N}{1-N}-\frac{K}{M} M_{K}\right)} .
\end{aligned}
$$

To gain an intuitive understanding of the forces which shape the second-best optimal mix of factor taxes under monopolistic wage-setting, it seems helpful, initially, to look at two clear-cut steady-state benchmark results which are summarized by the following two propositions:

Proposition 1 (First-best factor taxes and imperfectly competitive labour markets) If the implementability constraint is not binding $(\phi=0)$ and labour markets are imperfectly competitive $(M>1)$, the unconstrained socially optimal allocation can be implemented by subsidizing labour at the rate $\tau^{N}=1-M<0$ and leaving capital untaxed $\left(\tau^{K}=0\right)$.

Remark: The unconstrained socially optimal allocation is given by the solution of the problem $(\mathrm{P})$ of the social planner:

$$
\begin{gathered}
\max u\left(C_{t}, 1-N_{t}\right) \\
\text { s.t. } K_{t+1}=F\left(K_{t}, N_{t}\right)+(1-\delta) K_{t}-G-C_{t}, \quad K_{0} \text { given. }
\end{gathered}
$$

Denote this solution by $\left\{\widehat{K_{t}}, \widehat{N_{t}}, \widehat{C}_{t}\right\}$ and assume $\phi=0$ in the Ramsey problem of maximizing (14). Then, $\left\{\widehat{K}_{t}, \widehat{N}_{t}, \widehat{C}_{t}\right\}$ solves (14) as well, and $\tau^{K}=0, \tau^{N}=1-M<0$ follows from (20)-(22). For the conjecture $\phi=0$ to be valid, however, at the prices associated with the allocation $\left\{\widehat{K}_{t}, \widehat{N}_{t}, \widehat{C}_{t}\right\}$ the inequality

$$
\widehat{u_{C}}(0)\left[\tau_{0}^{K} \cdot \widehat{r}_{0} \cdot K_{0}-B_{0}\right] \geq \sum_{t=0}^{\infty} \beta^{t}\left\{\widehat{u_{C}}(t)\left[G-(1-M) \widehat{w}_{t} \widehat{N}_{t}\right]\right\}
$$

needs to be satisfied. 
Proposition 1 summarizes basic insights from the static literature on labour market imperfections. From the first-order conditions of the unconstrained problem $(\mathrm{P})$ it is evident that a welfare-maximizing social planner would seek to implement a steadystate allocation which is characterized by the optimality conditions $F_{N}(K, N)=$ $u_{L} / u_{C}$ and $1=\beta\left(F_{K}(K, N)+1-\delta\right)$. To replicate these conditions in an (imperfectly) competitive equilibrium, as is inferred from the first-order conditions (9) and (10) of the representative household, taxes have to be set according to $\tau^{N}=1-M$ and $\tau^{K}=0$. This means that the inefficiency associated with monopolistic wage setting should be cured by subsidizing wages at a flat rate, while leaving capital untaxed. According to (20)-(22) this will indeed be optimal from the Ramsey perspective if the implementability constraint is non-binding $(\phi=0)$. This in turn requires, as summarized by (23), that the government's initial net lending position vis-à-vis the private sector is sufficiently strong (i.e. $B_{0}$ sufficiently negative) or that the initial tax on capital $\tau_{0}^{K}$ is sufficiently large to ensure that the entire sequence of future government expenditures (inclusive the corrective wage subsidies) can be financed without resorting to distortionary taxes. ${ }^{6}$

We turn now to constellations in which the unconstrained social optimum cannot be implemented and present the second benchmark result.

\section{Proposition 2 (Second-best factor taxes and competitive labour markets)} If the implementability constraint is binding $(\phi>0)$ and wages are set in a competitive manner $(M \equiv 1)$, then: (i) $\tau^{K}=0$ and $\left(\right.$ ii) $\tau^{N}>0$.

Part (i) of Proposition 2 restates the result by Chamley (1986) and Judd (1985) that in a fully competitive setting under second-best taxation it is too costly to distort the intertemporal margin of optimality, making the labour tax the preferred

\footnotetext{
${ }^{6}$ If (23) holds as a strict inequality, the difference between the initial wealth position of the government and the present value of its expenditures needs to be rebated to households in a lump-sum manner.
} 
instrument. Note, however, the well-known tension between the time-zero capital tax rate (to be set as high as possible in order to reduce the shadow value $\phi$ of the implementability constraint) and the steady-state result of a zero-capital tax rate. ${ }^{7}$ Moreover, equations (21)-(22) show that the steady-state level of the labour tax which corresponds to the Chamley-Judd capital taxation result typically cannot be inferred from steady-state quantities alone. Instead, it depends through the value of the implementability constraint $\phi$ on the entire sequence of equilibrium conditions and the initial wealth positions, as discussed in further detail by Chamley (1985, 1986) and Lucas (1990). Our simplifying separability assumption regarding $u(C, L)$, however, is a particularly simple sufficient condition for the steady-state value of $\tau^{N}$ to be always positive, ensuring that the entire steady-state tax burden falls on labour. ${ }^{8}$

Building on these two benchmark results, we now discuss a constellation with imperfectly competitive labour markets $(M>1)$ under distortionary, second-best taxation requirements $(\phi>0)$. In the light of the lemma established above we distinguish between wage mark-ups which are constant or, alternatively, depend on the capital intensity of production.

\footnotetext{
${ }^{7}$ Related to this tension, Lansing (1999) shows that under the specific assumption of logarithmic utility (which removes anticipation effects of changes in future return rates) and a balanced budget requirement (which removes the possibility to 'store' distortionary taxation revenues) the front loading of distortionary taxation ceases to be optimal, implying $\tau^{K}>0$ in the long run. For a discussion of associated time-consistency issues, see also Section 4.

${ }^{8}$ If one allows for $u_{C L} \neq 0$ (and assumes $M \equiv 1$ ), (22) turns into

$$
z(M)=\frac{1+\phi\left(1+u_{C C} \frac{C}{u_{C}}-\frac{u_{L C}}{u_{C}} N\right)}{1+\phi\left(1-u_{L L} \frac{L}{u_{L}} \frac{N}{1-N}+\frac{u_{L C}}{u_{C}} C\right)} .
$$

Hence, concavity of $u(C, L)$ is no longer sufficient to ensure $\tau^{N}>0$ if $\phi>0$. Note, however, that assuming a constant stream of government expenditures $G>0$, the outcome $\tau^{N}>0$ is consistent with the consumption smoothing results of Lucas and Stokey (1983).
} 
Proposition 3 (Second-best factor taxes and imperfectly competitive labour markets)

Assume the implementability constraint is binding $(\phi>0)$ and wages are set with a mark-up $M>1$.

i) If $M>1$ is constant (as implied by the Cobb-Douglas case with $\sigma=1$ ), then $\tau^{K}=0, \tau^{N}>0$.

ii) If $M>1$ is non-constant, then $\tau^{K}\left\{\begin{array}{c}<0 \text { if } \sigma<1 \\ >0 \text { if } \sigma>1\end{array}\right.$ and, ceteris paribus, $\tau^{N}$ will be larger (smaller) than in the case of Cobb-Douglas production if $\sigma<1(>1)$.

Regarding part (i) of Proposition 3, the term 1/M in equation (22) indicates, ceteris paribus, the desirability of correcting for the labour market distortion. However, as long as the mark-up $M$ is constant, the labour market distortion cannot be indirectly alleviated by taxing or subsidizing capital. Clearly, as assumed in part (ii) of Proposition 3, this is different if $M(k)$ depends on the mix of factor inputs. Then, since $M_{K}=M_{k} / N \neq 0$, taxing or subsidizing capital income can be used as an indirect tool for mitigating the wage-setting power of households in the labour market. More precisely, capital should be taxed (subsidized) whenever the markup rises (falls) in the capital stock, or, equivalently, whenever $\sigma>1(\sigma<1)$. Corresponding to this finding, since $M_{K}$ enters the expressions for $\tau^{K}$ and $\tau^{N}$ with opposite sign, the labour tax should be used in an offsetting manner, which is to say that, ceteris paribus, labour should be less (more) strongly taxed than in the case of a constant mark-up whenever $\sigma>1(\sigma<1){ }^{9}$

\footnotetext{
${ }^{9}$ This statement is subject to the qualification that competitive equilibria with different values of $M$ will also be characterized by different steady state values of the other endogenous varaiables, including $\phi$. Thus, quantifying the labour-market related subsidy-component of the $\tau^{N}$-schedule in a comparative manner would require simulations in order to capture all general equilibrium feedback effects.
} 
In sum, the main finding of this section is that in a dynamic Ramsey setting with imperfectly competitive labour markets the role of capital taxation tends to be aligned with the corrective taxation rather than the revenue motive, as long as there are no rents accruing to labour. Qualitatively, this confirms the findings of Guo and Lansing (1999) who, building on Judd (1997), study optimal tax policies in a setting with imperfectly competitive intermediate product markets. However, there are two key differences from our paper: i) the considered deviation from perfect competition affects the two inputs labour and capital in a perfectly symmetric manner; ii) because of their monopoly power, intermediaries earn pure economic profits which are treated for tax purposes, in the absence of a genuine profit tax, as capital income. The firstbest policy ('corresponding to $\phi=0$ ') is shown to consist of a uniform subsidy to both labour and capital, reflecting the first difference. More specifically, the subsidies are required in order to correct for differences between the private and the social returns to the inputs. From a second-best taxation perspective, the tax on labour is positive, while the sign of the steady-state capital tax rate is ambiguous owing to the 'underinvestment' and the 'profit' effect, reflecting the second difference. ${ }^{10}$ However, Guo and Lansing (1999) show that if profits can be fully taxed by means of a genuine profit tax, the entire tax burden falls on labour, while capital should be subsidized in order to correct for the suboptimal level of investment. This latter finding is conceptually in line with our Proposition 3. The fact that in our analysis the sign of the second-best capital tax rate is a priori ambiguous simply reflects the fact that capital may need to be taxed or subsidized in order to mitigate the wage setting power of households, depending on whether in the aggregate production function the elasticity $\sigma$ is assumed to be larger or less than unity.

\footnotetext{
${ }^{10}$ As shown by the authors, this result needs some further modification if the tax treatment of capital depreciation introduces additional distortions.
} 


\section{Optimal taxation under right-to-manage wage bargaining: the role of unemployment benefits}

This section extends the previously studied economy and allows for a richer, less centralized wage-setting process in which both firms and households decide on the wage and in which the outcome of the bargain depends on the level of unemployment benefits and the aggregate unemployment rate, much as in Layard, Nickell, and Jackman (1991). Since versions of this set-up have been widely used in the past to study labour market issues in economies in which a large part of the workforce earns wages that result from collective wage bargaining agreements, we find it natural to proceed along these lines. Given our discussion in section 2, however, it should be clear that qualitatively the results derived below are not restricted to this particular set-up. More specifically, we now assume that the economy is characterized by a large number of symmetric sectors. Each sector consists of infinitely many small firms and households of measure 1. Within each sector, firms and households are organized in an employer's federation and a union, respectively, and we consider a representative, sector-specific bargain of the right-to-manage type which determines $w$, while the employment level is decided by firms. Conceptually, this modification implies that the simple wage mark-up in the first-order condition (10) from the household's problem derived under monopolistic wage-setting will now be replaced by a richer expression, describing the outcome of the right-to-manage bargain in a symmetric equilibrium.

The representative household has in each period a time endowment of $L^{e}=1$, which is inelastically supplied. Wage contracts last for one period and, depending on the outcome of the bargain, a fraction $N$ of households will be employed at the net wage rate $w\left(1-\tau^{N}\right)$, while a fraction $1-N$ remains unemployed and receives benefits $b$. Investment and savings decisions are made before the bargain takes place. As 
above, there is no strategic interaction between the wage-setting decision and the process of capital formation, since firms within each sector are 'small', i.e. the period- $t$ wage bargain takes the sector-wide capital stock $K_{t}$ as given. Moreover, savings of households are diversified over all sectors, representing claims against the aggregate capital stock. Since the representative sector is assumed to be small compared with the rest of the economy, future factor returns are taken as exogenous in the wage bargain. We introduce some turnover between the sectors to ensure that the wage-setting behaviour in the representative sector takes the aggregate employment situation into account as well. In particular, using the specification of Layard, Nickell, and Jackman (1991, chapter 2), the outside option ( $\underline{w})$ maintained in the representative bargain in period $t$ is specified as

$$
\underline{w}_{t}=\left(1-\chi u_{t}\right) w_{t}^{e}\left(1-\tau_{t}^{N}\right)+\chi u_{t} b_{t}
$$

where $u$ denotes the (expected) economy-wide unemployment rate, $w^{e}$ is the expected average wage rate across sectors and $\chi$ with $(1<\chi<1 / u)$ is a measure of turnover between sectors after the wage has been set. ${ }^{11}$ Let the relative bargaining power of the union be denoted by $\gamma$ and consider the Nash bargain in period $t$, with $\tau^{N}, K$ and $\underline{w}$ taken as given:

$$
\max _{w_{t}}\left\{\left(w_{t}\left(1-\tau_{t}^{N}\right)-\underline{w}_{t}\right) N\left(K_{t}, w_{t}\right)\right\}^{\gamma} \cdot\left\{F\left(K_{t}, N\left(K_{t}, w_{t}\right)\right)-w_{t} N\left(K_{t}, w_{t}\right)\right\}^{1-\gamma}
$$

The first-order condition regarding the wage rate is given by

$$
\gamma \frac{\left(1-\tau_{t}^{N}\right) N_{t}+\left(w_{t}\left(1-\tau_{t}^{N}\right)-\underline{w}_{t}\right) N_{w}(t)}{\left(w_{t}\left(1-\tau_{t}^{N}\right)-\underline{w}_{t}\right) N_{t}}=(1-\gamma) \frac{N_{t}}{F_{t}-w_{t} N_{t}} .
$$

Since all sectors are identical, a symmetric equilibrium requires $w^{e}=w, u=1-N$, yielding the following expression for the surplus of the net wage over the outside

\footnotetext{
${ }^{11}$ If there is zero turnover across sectors $(\chi \rightarrow 1 / u)$, the outside option is determined solely by unemployment benefits. The relative importance of benefits decreases in job turnovers, i.e. it is smallest if there is complete turnover $(\chi \rightarrow 1)$. For a discussion of the reduced-form equation $(24)$ in a related model, see also Kaas and von Thadden (2002).
} 
option

$$
w_{t}\left(1-\tau_{t}^{N}\right)-\underline{w}_{t}=\chi\left(1-N_{t}\right)\left(w_{t}\left(1-\tau_{t}^{N}\right)-b_{t}\right) .
$$

As we show in the following two subsections, the factor taxation results depend sensitively on how the level of unemployment benefits $b$ is specified in the outside option $\underline{w}$. To simplify the exposition, we restrict the analysis to the case of a CES production function with properties as established in Section 2.1.

\subsection{Non-indexed unemployment benefits}

We assume first that unemployment benefits $b_{t}$ are set at some exogenously specified level $b>0$. Then, as derived in part 2 of the appendix, the net wage resulting from the bargain can be expressed as, upon using (27) in (26):

$$
\begin{aligned}
w_{t}\left(1-\tau_{t}^{N}\right) & =b \frac{1}{1-\frac{1}{\chi\left(1-N_{t}\right) \xi\left(k_{t}\right)}} \\
\xi\left(k_{t}\right) & =\eta\left(k_{t}\right)+\frac{1-\gamma}{\gamma} \cdot \frac{\eta\left(k_{t}\right)-\sigma}{\sigma} .
\end{aligned}
$$

Equation (28) generalizes the set-up of the previous section as now the net wage depends on the wage elasticity of labour demand $(\eta)$, the unemployment benefit level $(b)$, the relative bargaining power of the two sides $((1-\gamma) / \gamma)$, the turnover between sectors $(\chi)$ and the steady-state unemployment rate $(u=1-N)$. For further reference, we emphasize that the mark-up of the net wage over unemployment benefits declines, ceteris paribus, in the wage elasticity of labour demand. The total income of households obtained in the labour market (i.e. inclusive of unemployment benefits), denoted $\widetilde{w}$, is given by

$$
\begin{aligned}
\widetilde{w}_{t} & =N_{t} w_{t}\left(1-\tau_{t}^{N}\right)+\left(1-N_{t}\right) b \\
& =\left(1+\frac{N_{t}}{\chi\left(1-N_{t}\right) \xi\left(k_{t}\right)-1}\right) b .
\end{aligned}
$$

Note that $\widetilde{w}$ is independent of prices and taxes, which means that we can use it as an alternative to equation (10) to replace the term $\left(1-\tau^{N}\right) w N$ in the implementability 
constraint. Since labour is inelastically supplied at the individual level, we suppress it in the flow utility of the representative household. ${ }^{12}$ Upon these changes, the flow objective of the pseudo-planning problem becomes

$$
V\left(C_{t}, N_{t}, K_{t}, \phi\right)=u\left(C_{t}\right)+\phi\left[u_{C}(t)\left(C_{t}-\widetilde{w}_{t}\left(N_{t}, K_{t}\right)\right)\right],
$$

Using (30) in (14), the following is obtained from the first-order condition of the Ramsey problem with respect to $K_{t+1}$ :

$$
\begin{aligned}
\theta_{t} & =\beta\left\{\theta_{t+1}\left[F_{K}(t+1)+1-\delta\right]+V_{K}(t+1)\right\} \\
& =\beta\left\{\theta_{t+1}\left[F_{K}(t+1)+1-\delta\right]-\phi u_{C}(t+1) \widetilde{w}_{\xi}(t+1) \xi_{K}(t+1)\right\}
\end{aligned}
$$

Combining this with the no-arbitrage condition from the consumer's problem, as given by (9), yields for the steady-state tax rate on capital:

$$
\tau^{K}=\frac{\phi}{V_{C}} \frac{u_{C}}{F_{K}} \widetilde{w}_{\xi} \xi_{K}
$$

Examining (31) leads to:

Proposition 4 If the implementability condition is binding $(\phi>0)$, the optimal steady-state tax rate on capital should be set according to

$$
\tau^{K}\left\{\begin{array}{l}
<0 \text { if } \sigma<1 \\
=0 \text { if } \sigma=1 \\
>0 \text { if } \sigma>1
\end{array} .\right.
$$

\footnotetext{
${ }^{12}$ More specifically, households offer their labour supply inelastically to the union which represents them in the bargain. Hence, by making the simplifying assumption $u(C, 1-N)=u(C)$ we assume that the disutility of labour does not depend on the employment status. This can be rationalized, for example, by assuming that benefits are handed out only in return for the participation in some training activity which keeps the human capital of unemployed people intact, but does not contribute to the per household output measure $F(K, N)$.
} 
Remark: The result follows from $\xi_{K}=\xi_{k} / N, \operatorname{sign}\left(\xi_{k}\right)=\operatorname{sign}\left(\eta_{k}\right)$ and the properties of $\eta$ established for the Lemma in Section 2.1. Since $\widetilde{w}_{\xi}<0, \operatorname{sign}\left(\tau^{K}\right)=-\operatorname{sign}\left(\eta_{k}\right)$.

Despite the different labour market specification, Proposition 4 essentially replicates the main finding of Proposition 3, which states that the steady-state capital tax should be non-zero whenever the wage elasticity of labour demand depends on the capital intensity of production. The main reason for this is as follows: Although the labour supply is assumed to be inelastic at the individual level, employment is elastic at the sectoral level at which the representative wage bargain takes place. One of the key determinants of employment is the size of the mark-up of wages over unemployment benefits which depends, ceteris paribus, on the wage elasticity of labour demand. Hence, similar to Proposition 3, the long-run employment level may depend on the level of the capital stock, and, whenever this is the case, there is scope for a non-zero capital tax to be used according to the corrective taxation motive.

\subsection{Unemployment benefits indexed to the net wage}

Assume now that unemployment benefits are proportional to the net wage so that

$$
b_{t}=\lambda w_{t}\left(1-\tau_{t}^{N}\right), \quad \lambda>0
$$

Using equation (32) we obtain for the difference between the net wage rate and the outside option

$$
w_{t}\left(1-\tau_{t}^{N}\right)-\underline{w}_{t}=\chi\left(1-N_{t}\right)(1-\lambda) w_{t}\left(1-\tau_{t}^{N}\right) \text {. }
$$

Using (33) in (26), one can easily confirm that now the labour market allocation no longer depends on the labour tax rate $\tau^{N}$, since changes in $\tau^{N}$ leave the relative importance of the inside and outside option unaffected, as discussed in more detail, 
for example, in Pissarides (1998). More precisely, substituting (33) into (26) gives

$$
\begin{aligned}
w_{t} & =F_{N}\left(K_{t}, N_{t}\right)=w\left(k_{t}\right) \\
N_{t} & =1-\frac{1}{(1-\lambda) \chi \xi\left(k_{t}\right)}=N\left(k_{t}\right),
\end{aligned}
$$

where (35) defines implicitly some relationship between the levels of employment and capital. Hence, under the assumption of indexed unemployment benefits the total labour market income $\widetilde{w}$ can be expressed as

$$
\widetilde{w}_{t}=N_{t} w_{t}\left(1-\tau_{t}^{N}\right)+\left(1-N_{t}\right) \lambda w_{t}\left(1-\tau_{t}^{N}\right)=\left(1-\tau_{t}^{N}\right) w_{t}\left[N_{t}(1-\lambda)+\lambda\right]
$$

Since the labour market allocation (34) and (35) is not affected by changes in $\tau^{N}$, there is a rent accruing to labour which can be taxed away without deadweight loss, with the rent $R$ being given by

$$
R_{t}=w_{t}\left[N_{t}(1-\lambda)+\lambda\right]=R\left(k_{t}\right) .
$$

Before we proceed, we point out that (36) is a generalization of the case of a rent considered in Jones, Manuelli, and Rossi (1997) who analyze an economy with a fully competitive labour market in which labour is in fixed supply $(N=1)$ and $\lambda=0$. Hence the rent in their model is simply the gross wage rate, i.e. $R=w$. Equation (36) generalizes this idea since the rate $N$ at which labour is employed, although being independent of $\tau^{N}$, is no longer fixed, but results instead from the bargain and depends on the capital intensity $k_{t}$. Thus, the size of the rent to labour depends now on the wage rate $w(k)$ and on the employment rate $N(k)$. To keep the following analysis meaningful, we follow Jones, Manuelli, and Rossi (1997) and assume that the rent cannot be fully taxed (because of some exogenous upper bound for the tax rate on labour $\tau^{N}=\overline{\tau^{N}}<1$ ) and that in steady state the labour tax revenue $\overline{\tau^{N}} R$ is not sufficient to cover all government expenditures. Hence, the flow objective and the Lagrangian of the pseudo-planning problem become, respectively,

$$
V\left(C_{t}, N_{t}, K_{t}, \phi\right)=u\left(C_{t}\right)+\phi\left\{u_{C}(t)\left(C_{t}-\left(1-\overline{\tau^{N}}\right) R_{t}\right)\right\}
$$




$$
J=\sum \beta^{t}\left\{V\left(C_{t}, N_{t}, K_{t}, \phi\right)+\theta_{t}\left[F\left(K_{t}, N_{t}\right)+(1-\delta) K_{t}-G-C_{t}-K_{t+1}\right]\right\}-\phi A .
$$

The first-order condition of (38) with respect to $K_{t+1}$ is given by

$$
\begin{aligned}
\theta_{t} & =\beta\left\{\theta_{t+1}\left[F_{K}(t+1)+1-\delta\right]+V_{K}(t+1)\right\} \\
V_{K}(t+1) & =-\left(1-\overline{\tau^{N}}\right) \phi u_{C}(t+1) R_{K}(t+1) .
\end{aligned}
$$

Accordingly, the steady-state capital tax rate can be expressed as

$$
\begin{aligned}
\tau_{K} & =\frac{\left(1-\overline{\tau^{N}}\right) \phi u_{C}}{V_{C} F_{K}} R_{K} \\
R_{K} & =F_{N K}(N(1-\lambda)+\lambda)+F_{N} N_{K}(1-\lambda),
\end{aligned}
$$

where $w=F_{N}$ has been used in deriving (42). This leads us to

Proposition 5 Under proportional unemployment benefits there exists a rent in the labour market. If this rent cannot be fully taxed $\left(\tau^{N}=\overline{\tau^{N}}<1\right)$ and the implementability constraint is binding $(\phi>0)$, the optimal steady-state capital tax rate $\tau^{K}$ is positive whenever the rent increases in the capital stock. This will always be the case for $\sigma \leq 1$, while the effect on $\tau^{K}$ is a priori ambiguous for $\sigma>1$.

Remark: According to (35), $\operatorname{sign}\left(\xi_{k}\right)=\operatorname{sign}\left(N_{k}\right)$. Thus, $N_{K}=N_{k} \frac{1}{N}=0$ if $\sigma=1$, and $N_{K}>0(<0)$ if $\sigma<1(\sigma>1)$, while $F_{N K}>0$ will be satisfied irrespective of how $\sigma$ relates to unity.

Proposition 5 is a generalization of the rent result of Jones, Manuelli, and Rossi (1997) who show that the steady-state capital tax should be positive whenever the capital stock and the (non-fully taxable) rent are positively correlated, requiring in their set-up simply $w_{K}=F_{N K}>0 .{ }^{13}$ However, as a key difference, the total

\footnotetext{
${ }^{13}$ In related work, Correia (1996) considers a competitive economy with constant returns to scale in labour, capital and a third input which cannot be taxed and earns a rent. She shows that the steady-state tax rate on capital should be positive (negative) whenever capital and the third factor enter the production function as complements (substitutes), a finding which is qualitatively in accordance with the intuition given above.
} 
effect of the capital stock on the size of the rent can now be decomposed into a 'wage' and an 'employment' effect. In the special case of a Cobb-Douglas function $(\sigma=1)$ the employment rate consistent with the bargaining outcome is in 'fixed' supply, i.e. the employment effect is zero and, according to (42), $\tau^{K}>0$ obtains because of $w_{K}=F_{N K}>0$, as in Jones, Manuelli, and Rossi (1997). ${ }^{14}$ By contrast, if $\sigma \neq 1$, the employment rate depends on the level of the capital stock. Under gross complementarity $(\sigma<1)$, the steady-state employment rises in the capital stock, thereby increasing the rent, i.e. the two effects reinforce each other, calling unambiguously for a positive capital tax rate. Correspondingly, if $\sigma>1$ the two effects operate in different directions, making the overall effect a priori ambiguous. This ambiguity, however, does not imply that under $\sigma>1$ the capital tax rate $\tau_{K}$ must be lower than in the Cobb-Douglas case. The reason for this is that the weights of the two effects depend on the replacement ratio $\lambda$. Assume, for example, that $\lambda$ is 'high' (i.e. close to 1), ensuring a comparatively low level of steady-state employment. Then, the employment effect carries a low weight, while the wage effect associated with $\sigma>1$ may well outweigh the total effect under $\sigma=1$.

In any case, the main message of this section is that the second-best role of capital taxation is significantly altered once imperfectly competitive labour markets are characterized by rents which cannot be directly taxed away. In particular, our results indicate that whenever the rent correlates positively with the long-run capital stock the capital tax should be positive to counteract the rent-creation process. We are aware that our particular set-up, with only two inputs, suffers from the limitation that the assumption of a non-fully taxable rent automatically imposes some exogenous upper bound for the labour tax rate. This is not an entirely satisfactory

\footnotetext{
${ }^{14}$ The property $w_{K}=F_{N K}>0$ follows from the assumptions regarding $F(K, N)$ made at the outset. In particular, this condition is certainly always satisfied by a CES function, irrespective of the size of the elasticity of substitution between labour and capital.
} 
feature and we therefore leave to future work a reexamination of the results of this final section in a setting which allows, for example, for a third input which cannot be taxed along the lines of Correia (1996) and, at the same time, maintains the notion of imperfectly competitive labour markets.

\section{Related literature}

This section briefly discusses our main findings in the context of related literature. First, to our knowledge, the role of imperfectly competitive labour markets in the design of second-best optimal factor taxes has not yet been explored in dynamic settings which allow for aspects of capital accumulation. However, our steady-state results can, naturally, be linked to static, open-economy frameworks in which the return to capital is taken as given from the world market and the capital (labour) endowment is assumed to be perfectly mobile (immobile). Richter and Schneider (2001) derive for the monopoly union case, similar to the reasoning behind our Proposition 3, a role of a non-zero capital tax rate as an indirect tool for reducing the wage-setting power of the union. ${ }^{15}$ Similarly, Koskela and Schöb (2002) consider a labour market which is subject to right-to-manage wage bargaining and derive capital taxation results which have some resemblance to our Proposition 4. Moreover, in line with our discussion in Section 2 of the 'profit effect' established in Guo and Lansing (1999), the two papers report that the role of capital taxation will be strengthened if profits cannot be fully taxed. Finally, Bovenberg and van der Ploeg (1996), in a different set-up which abstracts from capital taxation issues, discuss the conflict which arises if a positive labour tax is needed for generating revenues

\footnotetext{
${ }^{15}$ The taxation findings of Richter and Schneider (2001) for the CES case in Proposition 7 (p. 254) differ from ours, however, since in their set-up profit-maximizing firms simultaneously choose optimal levels of labour and capital. By contrast, in our set-up capital is a predetermined variable regarding the employment decision of firms.
} 
under distortionary taxation, although a wage subsidy would be required to correct for some labour market inefficiency.

Second, returning to the literature on dynamic Ramsey problems, results on secondbest optimal factor taxes are known to depend sensitively on the set of feasible tax instruments, as illustrated in Section 3.2. Along these lines, Coleman (2000) has recently re-emphasized that work in the Chamley-Judd-tradition, by excluding the possibility of consumption taxes, leads at best to restricted versions of the principle of uniform taxation. Upon including the additional instrument of a consumption tax, Coleman (2000) derives a uniform taxation result regarding consumption and leisure (implying that labour should be subsidized at the rate of the consumption tax) which restores the unconstrained social optimum without compromising on the zero-capital tax result. Coleman's analysis can easily be adapted to our set-up discussed in Section 2. In particular, allowing for a constant consumption $\operatorname{tax}\left(\tau^{C}\right)$, equation (9) in the crucial first-order conditions of the household remains unaffected, while (10) turns into:

$$
\frac{1-\tau^{N}}{1+\tau^{C}} \cdot w=\frac{u_{L}}{u_{C}} \cdot M
$$

Owing to the additional tax instrument, the unconstrained social optimum can now be restored if taxes are set according to $\left(1-\tau^{N}\right) /\left(1+\tau^{C}\right)=M$. Whenever $M>1$, one obtains $-\tau^{N}>\tau^{C}$, i.e. the labour market distortion strengthens the need to subsidize labour and thereby overturns the uniform taxation result which holds in a fully competitive setting.

Third, given the deliberately narrow focus of our analysis, we conclude with a brief account of contributions to the literature that establish alternative mechanisms which invalidate the Chamley-Judd taxation result. The following list, however, is certainly not exhaustive, and we concentrate on some recent contributions which 
we find particularly important. ${ }^{16}$ i) Erosa and Gervais (2002) show that in a lifecycle framework optimal tax plans are likely to require different steady-state tax rates over an individual's lifetime. Assuming an increasing leisure profile over the life-cycle of agents, the capital tax rate should be positive whenever age-specific tax schemes are not available. ii) Benhabib and Rustichini (1997), Phelan and Stacchetti (2001), and Klein and Ríos-Rull (2002) address the well-known time-inconsistency of the Chamley-Judd finding of a zero long-run capital tax, resulting from the fact that in any period the capital stock is in fixed supply. As succinctly summarized by Benhabib and Rustichini, "the time inconsistency of the solution is most extreme precisely at the steady state, when the tax on capital is smallest and the incentive to revise the plan in order to relieve the economy of distortionary labour taxes, the largest" (p. 233). Imposing the time-consistency of tax announcements as an additional constraint, simulation results reported in the three studies, however, disagree on whether sustainable, time-consistent plans call for capital taxes or subsidies. iii) Stressing distributional aspects, Garcia-Milà, Marcet, and Ventura (2001) evaluate the welfare consequences of lowering capital taxes in a model with heterogenous agents. The main finding of the paper is that such a policy may well face a trade-off between the higher aggregate efficiency in production and the redistribution of wealth against agents with a low ratio of capital income over labour income. With a similar intention, Lansing (1999) and Krusell (2002) establish a redistributive role of steady-state capital taxation in a set-up with heterogenous agents which is similar to Judd (1985), but imposes time-consistent policies. iv) Introducing the notion of incomplete markets, Aiyagari (1995) considers a set-up in which agents face uninsurable idiosyncratic shocks and borrowing constraints. This motivates at the individual level precautionary savings, and the paper shows that

\footnotetext{
${ }^{16}$ For more comprehensive overviews of the literature, see, for example, Atkeson, Chari, and Kehoe (1999) and Ljungqvist and Sargent (2000, Chapter 12).
} 
a positive capital tax rate is required to prevent excessive capital formation. For a related analysis, see also Chamley (2001). v) Jones, Manuelli, and Rossi (1997) show, within a human capital set-up in which (effective) labour has a stock component similar to physical capital, that it may well be optimal to set both capital and labour taxes equal to zero in the long run. By implication, under such a scheme the government must acquire in the transition towards the steady state claims against the private sector which, in steady state, yield sufficient interest earnings to cover all government expenditures.

\section{Conclusion}

This paper studies features of optimal factor taxes under commitment in a representative agent, infinite horizon economy in which factor taxes are the only available tax instruments for financing some exogenously given stream of government expenditures. Distinguishing our work from the Chamley-Judd tradition, however, the labour market is assumed to be imperfectly competitive in the sense that wage markups resulting from a bargaining structure lead to a socially suboptimal employment level. To characterize second-best optimal taxes in line with these assumptions, we apply the logic of Ramsey-taxation exercises, i.e. we recognize that different tax schedules trigger different equilibrium reactions of agents which in turn will be associated with different (imperfectly) competitive equilibrium allocations. According to this logic, a benign social planner should choose that particular tax schedule which yields, in terms of the associated intertemporal allocation, the highest utility of the representative agent, taking as given the labour market constraint that it must be possible to decentralize the allocation through a wage bargain.

The main purpose of this paper is to show that the Chamley-Judd result which calls in steady state for a zero capital tax rate may well be invalidated under condi- 
tions of imperfectly competitive labour markets. At first sight this result may seem surprising since the assumed deviations from perfect competition are seemingly unrelated to capital and restricted to the labour market. However, the features of the labour market which we identify as potential sources of a non-zero capital tax rate have a clear appeal. First, we show that under a collective wage bargaining structure in which the representative firm is 'small' and its investment decision is made in a non-strategic manner, but the aggregate capital stock nevertheless acts as an important input for the wage-setting process, the return rates to capital as perceived by the private sector and by the Ramsey planner are likely to be different. More specifically, we show how in such a constellation a non-zero capital tax can have a role in correcting for the labour market distortion by mitigating the mark-up pricing of wage setters. Second, we show that the Chamley-Judd result vanishes when the wage bargaining specification gives rise to rents accruing to labour which cannot be directly taxed. In our set-up, this is the case if unemployment benefits are proportional to the net wage.

\section{References}

[1] Aiyagari, R., Optimal capital income taxation with incomplete markets, borrowing constraints, and constant discounting, Journal of Political Economy, 103, 6, 1158-75, 1995.

[2] Atkeson, A., Chari, V., and Kehoe, P., Taxing capital income: a bad idea, Federal Reserve Bank of Minneapolis Quarterly Review, 23, 3-17, 1999.

[3] Benhabib, J. and Rustichini, A., Optimal taxes without commitment, Journal of Economic Theory, 77, 231-259, 1997. 
[4] Bovenberg, A. and van der Ploeg, F., Optimal taxation, public goods and environmental policy with involuntary unemployment, Journal of Public Economics, 62, 59-83, 1996.

[5] Chamley, C., Efficient taxation in a stylized model of intertemporal general equilibrium, International Economic Review, 26, 2, 451-68, 1985.

[6] Chamley, C., Optimal taxation of capital income in general equilibrium with infinite lives, Econometrica, 54, 3, 607-22, 1986.

[7] Chamley, C., Capital income taxation, wealth distribution and borrowing constraints, Journal of Public Economics, 79, 55-69, 2001.

[8] Coleman II, W., Welfare and optimum dynamic taxation of consumption and income, Journal of Public Economics, 76, 1-39, 2000.

[9] Correia, I., Should capital income be taxed in the steady state, Journal of Public Economics, 60, 147-51, 1996.

[10] Diamond, P. and Mirrlees, J., Optimal taxation and public production I: production efficiency, American Economic Review, 61, 8-27, 1971.

[11] Erosa, A. and Gervais, M., Optimal taxation in life-cycle economies, Journal of Economic Theory, 105, 338-369, 2002.

[12] Gali, J., Non-walrasian unemployment fluctuations, NBER Working Paper, No. 5337, 1995.

[13] Gali, J., Unemployment in dynamic general equilibrium economies, European Economic Review, 40, 839-845, 1996. 
[14] Garcia-Milà, T., Marcet, A., and Ventura, E., Supply side intervention and redistribution, Department of Economics and Business, Universitat Pompeu Fabra, Working Paper, 2001.

[15] Guo, J. and Lansing, K., Optimal taxation of capital income with imperfectly competitive product markets, Journal of Economic Dynamics and Control, 23, 967-95, 1999.

[16] Jones, L., Manuelli, R., and Rossi, P., On the optimal taxation of capital income, Journal of Economic Theory, 73, 93-117, 1997.

[17] Judd, K., Redistributive taxation in a simple perfect foresight model, Journal of Public Economics, 28, 59-83, 1985.

[18] Judd, K., The optimal tax rate for capital income is negative, NBER Working Paper, No. 6004, 1997.

[19] Judd, K., Capital income taxation with imperfect competition, American Economic Review, Papers and Proceedings, 92, 417-21, 2002.

[20] Kaas, L. and von Thadden, L., Unemployment, factor substitution, and capital formation, German Economic Review, forthcoming, 2002.

[21] Klein, P. and Ríos-Rull, J., Time-consistent optimal fiscal policy, mimeo, 2002.

[22] Koskela, E. and Schöb, R., Optimal factor income taxation in the presence of unemployment, Journal of Public Economic Theory, 4, 387-404, 2002.

[23] Krusell, P., Time-consistent redistribution, European Economic Review, 46, 755-69, 2002.

[24] Lansing, K., Optimal redistributive capital taxation in a neoclassical growth model, Journal of Public Economics, 73, 423-53, 1999. 
[25] Layard, R., Nickell, S. and Jackman, R., Unemployment: macroeconomic performance and the labor market, Oxford University Press, 1991.

[26] Ljunqvist, L. and Sargent, T., Recursive macroeconomic theory, MIT Press, 2000 .

[27] Lucas, R., Supply-side economics: an analytical review, Oxford Economic Papers, 42, 293-316, 1990.

[28] Lucas, R. and Stokey, N., Optimal fiscal and monetary policy in an economy without capital, Journal of Monetary Economics, 12, 55-94, 1983.

[29] Phelan, C. and Stacchetti, E., Sequential equilibria in a Ramsey tax model, Econometrica, 69, 6, 1491-1518, 2001.

[30] Pissarides, C., The impact of employment tax cuts on unemployment and wages: the role of unemployment benefits and tax structure, European Economic Review, 42, 155-83, 1998.

[31] Richter, W. and Schneider, K., Taxing mobile capital with labor market imperfections, International Tax and Public Finance, 8, 245-62, 2001. 


\section{Appendix}

\section{Part 1}

The CES production function (11) implies, using $X=\alpha K^{\frac{\sigma}{\sigma-1}}+(1-\alpha) N^{\frac{\sigma-1}{\sigma}}, F_{N}=$ $(1-\alpha) X^{\frac{1}{\sigma-1}} N^{-\frac{1}{\sigma}}, F_{N N}=-\frac{\alpha(1-\alpha)}{\sigma} X^{\frac{2-\sigma}{\sigma-1}} N^{-\frac{(1+\sigma)}{\sigma}} K^{\frac{\sigma-1}{\sigma}}$. Implicitly differentiating the first-order condition $F_{N}(K, N)=w$, the wage elasticity of labour demand $\eta$ can be expressed as $\eta=-\frac{N_{w} w}{N}=-\frac{F_{N}}{N F_{N N}}$. Substituting out for $F_{N}$ and $F_{N N}$ and using $k=K / N, \eta$ turns out to be a function of the capital-labour ratio

$$
\eta=\sigma \frac{X}{\alpha\left[K^{\frac{\sigma-1}{\sigma}}\right]}=\sigma\left[\frac{1-\alpha}{\alpha} k^{\frac{1-\sigma}{\sigma}}+1\right]
$$

Since $M=\frac{\eta(k)}{\eta(k)-1}$ falls in $\eta$, for $\eta>1$, the sign of $\frac{\partial M}{\partial k}$ as established in the lemma follows immediately from (43).

\section{Part 2}

Suppressing time indices, the first-order condition regarding the wage rate as given by (26) can be rearranged to express the net wage rate in terms of the outside option $\underline{w}:$

$$
w\left(1-\tau^{N}\right)=\frac{\gamma \eta+(1-\gamma) \frac{s}{1-s}}{\gamma(\eta-1)+(1-\gamma) \frac{s}{1-s}} \underline{w},
$$

where $s=\frac{w N}{F(K, N)}$ describes the labour share. In the special case of a CES production function the labour share is given by the expression $s=\frac{1}{1+\frac{\alpha}{1-\alpha} k^{\frac{\sigma-1}{\sigma}}}$, implying $\frac{s}{1-s}=\frac{1-\alpha}{\alpha} k^{\frac{1-\sigma}{\sigma}}$. Combining this with the expression for the wage elasticity of labour demand derived in (43) gives $\frac{s}{1-s}=\frac{\eta(k)-\sigma}{\sigma}$. Upon isolating $\underline{w}$ in (27) and substituting into (44), one obtains equation (28) stated in the main text. 


\section{CESifo Working Paper Series}

(for full list see www.cesifo.de)

772 Seppo Honkapohja and Kaushik Mitra, Learning Stability in Economies with Heterogenous Agents, September 2002

773 David Laidler, Inflation Targets Versus International Monetary Integration - A Canadian Perspective, September 2002

774 Morten I. Lau, Panu Poutvaara, and Andreas Wagener, The Dynamic Cost of the Draft, September 2002

775 Steven Brakman, Harry Garretsen, and Charles van Marrewijk, Locational Competition and Agglomeration: The Role of Government Spending, September 2002

776 Anke S. Kessler and Christoph Lülfesmann, The Theory of Human Capital Revisited: On the Interaction of General and Specific Investments, September 2002

777 Kjell Erik Lommerud, Frode Meland and Lars Sørgard, Unionized Oligopoly, Trade Liberalization and Location Choice, September 2002

778 Antonio Merlo and François Ortalo-Magné, Bargaining over Residential Real Estate: Evidence from England, September 2002

$779 \mathrm{Yu}-\mathrm{Fu}$ Chen and Michael Funke, Exchange Rate Uncertainty and Labour Market Adjustment under Fixed and Flexible Exchange Rates, September 2002

780 Michael S. Michael, International Migration, Income Taxes and Transfers: A Welfare Analysis, September 2002

781 Clemens Fuest and Alfons Weichenrieder, Tax Competition and Profit Shifting: On the Relationship between Personal and Corporate Tax Rates, October 2002

782 Jan Bouckaert and Hans Degryse, Softening Competition by Enhancing Entry: An Example from the Banking Industry, October 2002

783 Johann K. Brunner and Susanne Pech, Adverse Selection in the Annuity Market with Sequential and Simultaneous Insurance Demand, October 2002

784 Gregory D. Hess and Eduard Pelz, The Economic Welfare Cost of Conflict: An Empirical Assessment, October 2002

785 Jan Erik Askildsen, Uwe Jirjahn, and Stephen C. Smith, Works Councils and Environmental Investment: Theory and Evidence from German Panel Data, October 2002

786 Geir H. Bjønnes, Dagfinn Rime, and Haakon O. Aa. Solheim, Volume and Volatility in the FX-Market: Does it matter who you are?, October 2002 
787 John Evans and John Fingleton, Entry Regulation and the Influence of an Incumbent Special Interest Group, October 2002

788 Wolfgang Ochel, International Comparisons and Transfer of Labour Market Institutions, October 2002

789 B. Gabriela Mundaca, Moral Hazard Effects of Bailing out under Asymmetric Information, October 2002

790 Gene M. Grossman and Edwin L.-C. Lai, International Protection of Intellectual Property, October 2002

791 John Hassler, José V. Rodriguez Mora, Kjetil Storesletten, and Fabrizio Zilibotti, A Positive Theory of Geographic Mobility and Social Insurance, October 2002

792 Paul De Grauwe and Marianna Grimaldi, The Exchange Rate in a Model with Heterogeneous Agents and Transactions Costs, October 2002

793 Guido Friebel and Mariassunta Giannetti, Fighting for Talent: Risk-shifting, Corporate Volatility, and Organizational Change, October 2002

794 Jan Erik Askildsen, Badi H. Baltagi, and Tor Helge Holmås, Will Increased Wages Reduce Shortage of Nurses? A Panel Data Analysis of Nurses' Labour Supply, October 2002

795 Marko Köthenbürger and Panu Poutvaara, Social Security Reform and Intergenerational Trade: Is there Scope for a Pareto-Improvement?, October 2002

796 Paul De Grauwe and Laura Rinaldi, A Model of the Card Payment System and the Interchange Fee, October 2002

797 Volker Böhm and Tomoo Kikuchi, Dynamics of Endogenous Business Cycles and Exchange Rate Volatility, October 2002

798 Mariam Camarero, Javier Ordóñez, and Cecilio Tamarit, The Euro-Dollar Exchange Rate: Is it Fundamental?, October 2002

799 Misa Tanaka, How Do Bank Capital and Capital Adequacy Regulation Affect the Monetary Transmission Mechanism?, October 2002

800 Jörg Baten and Andrea Wagner, Autarchy, Market Disintegration, and Health: The Mortality and Nutritional Crisis in Nazi Germany, 1933-1937, October 2002

801 Saku Aura, Uncommitted Couples: Some Efficiency and Policy Implications of Marital Bargaining, October 2002

802 Wolfram F. Richter, Delaying Integration of Immigrant Labor for the Purpose of Taxation, October 2002

803 Gil S. Epstein and Shmuel Nitzan, The Politics of Randomness, October 2002 
804 John Hassler and José V. Rodriguez Mora, Should UI Benefits Really Fall over Time?, October 2002

805 Friedrich Breyer and Stefan Felder, The Dead-anyway Effect Revis(it)ed, October 2002

806 Assar Lindbeck and Solveig Wikström, E-exchange and the Boundary between Households and Organizations, November 2002

807 Dieter Bös, Contests Among Bureaucrats, November 2002

808 Steven Brakman, Harry Garretsen, and Marc Schramm, The Strategic Bombing of German Cities during World War II and its Impact on City Growth, November 2002

809 Florian Englmaier and Achim Wambach, Contracts and Inequity Aversion, November 2002

810 Sarbajit Sengupta, Delegating Recruitment under Asymmetric Information, December 2002

811 Rajshri Jayaraman, On the Partial Public Provision of a Private Good, December 2002

812 Stéphanie Stolz, Banking Supervision in Integrated Financial Markets: Implications for the EU, December 2002

813 Christian Keuschnigg, Taxation of a Venture Capitalist with a Portfolio of Firms, December 2002

814 Inés Macho-Stadler and David Pérez-Castrillo, Settlement in Tax Evasion Prosecution, December 2002

815 Rainer Niemann and Dirk Simons, Costs, Benefits, and Tax-induced Distortions of Stock Option Plans, December 2002

816 Jan-Egbert Sturm and Barry Williams, Deregulation, Entry of Foreign Banks and Bank Efficiency in Australia, December 2002

817 V. Anton Muscatelli, Patrizio Tirelli, and Carmine Trecroci, Monetary and Fiscal Policy Interactions over the Cycle: Some Empirical Evidence, December 2002

818 Claude Hillinger, A General Theory of Price and Quantity Aggregation and Welfare Measurement, December 2002

819 Erkki Koskela and Ronnie Schöb, Optimal Capital Taxation in Economies with Unionised and Competitive Labour Markets, December 2002

820 Sheilagh Ogilvie, Guilds, Efficiency, and Social Capital: Evidence from German ProtoIndustry, December 2002

821 Hans Gersbach and Verena Liessem, Financing Democracy, December 2002 
822 Costas Hadjiyiannis, Panos Hatzipanayotou, and Michael S. Michael, Optimal Tax Policies with Private-Public Clean-Up, Cross-Border Pollution and Capital Mobility, December 2002

823 François Ortalo-Magné and Sven Rady, Homeownership: Low Household Mobility, Volatile Housing Prices, High Income Dispersion, December 2002

824 Syed M. Ahsan and Panagiotis Tsigaris, Measuring the Social Discount Rate under Uncertainty: A Methodology and Application, December 2002

825 Kai A. Konrad, Altruism and Envy in Contests: An Evolutionarily Stable Symbiosis, December 2002

826 Robert S. Chirinko and Huntley Schaller, A Revealed Preference Approach to Understanding Corporate Governance Problems: Evidence from Canada, December 2002

827 Geir B. Asheim, Green National Accounting for Welfare and Sustainability: A Taxonomy of Assumptions and Results, December 2002

828 Andrea Gebauer, Chang Woon Nam, and Rüdiger Parsche, Lessons of the 1999 Abolition of Intra-EU Duty Free Sales for Eastern European EU Candidates, December 2002

829 Giacomo Corneo, Work and Television, December 2002

830 Vivek H. Dehejia and Yiagadeesen Samy, Trade and Labour Standards - Theory, New Empirical Evidence, and Policy Implications, December 2002

831 Geir B. Asheim and Wolfgang Buchholz, A General Approach to Welfare Measurement through National Income Accounting, December 2002

832 Aaron Tornell and Frank Westermann, The Credit Channel in Middle Income Countries, January 2002

833 Gebhard Flaig, Time Series Properties of the German Monthly Production Index, January 2002

834 Campbell Leith and Jim Malley, Estimated Open Economy New Keynesian Phillips Curves for the G7, January 2002

835 Burkhard Heer and Bernd Süssmuth, Inflation and Wealth Distribution, January 2002

836 Erkki Koskela and Leopold von Thadden, Optimal Factor Taxation under Wage Bargaining - A Dynamic Perspective, January 2002 